the real one. Schiaparelli detected the dynamical explanation of the fact that the swarm is lengthened out like a stream along a portion of Adams's orbit. And Leverrier adduced evidence that the Leonids have been less than eighteen centuries within the solar system : that in fact they were diverted into their present eiliptic orbit at the end of February or beginning of March in the year A.D. I26, in consequence of having then passed, while still a compact cluster, close to the planet Uranus. Adams further pointed out that there is a comet moving nearly in their track.

These were great achievements ; of which the most noteworthy is the great discovery made by Prof. Adams when he determined definitely the real orbit in which these bodies move. This he accomplished by computing the perturbations which would be suffered in each of the five possible orbits, and comparing the calculated amount of the shift of the nodes with that which had been obtained by comparing the ancient with recent observations.

The main swarm of Leonids is again returning. A shower of several hundreds of meteors, produced by the extreme front of the ortho-stream, was observed last November in America. Still greater showers may be expected this year and next year, and perhaps a considerable display in the year following; and it is eminently desirable that this opportunity of increasing our knowledge in this entirely new branch of astronomy shall not be lost. It is the second occasion when astronomers have been able to foresee when the opportunity is about to present itself.

In 1866 , the great object was to ascertain the orbit. To determine this, what was wanted was the average amount of the perturbations, and it was this average which Adams computed. But to make a further advance-to explore more fully the past history of the Leonids, or their present condition, or to predict the future - a more intimate acquaintance with the perturbations is essential. Now perturbations reach each meteor individually. They differ from one revolution to another, and within each revolution they variously affect the meteors that occupy different stations along the stream.

The present investigation was entered on as a commencement of the more searching inquiry indicated above. The stream is regarded as divided into segments of such noderate length that the perturbations which operate on the meteors occupying any one of them may be regarded as sensibly the same. One of these segments is selected-that through which the Earth passed in $1866-$ and the actual perturbations to which the elements of its orbit are being subjected thronghout an entire revolution, have been computed by the method of mechanical quadratures. The revolution extends from I $866^{\circ}$ November 13 , when the Earth passed through this segment of the stream, till 1900 January 27 , when the same segment will return to the intersection of the meteoric orbit with the Earth's orbit.

The inquiry has already led to remarkable results. During this revolution an entirely abnormal amount of perturbation has acted on the meteors in the selected segment of the stream. This perturbation has been produced chiefly by the attraction exercised by the great planets Jupiter and Saturn, and its unusual amount has been occasioned by a near approach of Saturn when that segment of the stream, for which the calculations were made, was on its outward journey, and a still more close approach of Jupiter, when the meteors were on their homeward journey. These events have resulted in such a perturbation of the orbit, that the shift of its node during this revolution has had more than $3 \frac{2}{2}$ times its average amount, and that the periodic time has become augmented by as much as $\frac{1}{3}$ of a year.

This last perturbation will have a remarkable effect on the future history of this segment of the stream, unless it is compensated by what occurs elsewhere or in subsequent revolutions It indicates, too, that whatever portion of the stream has been most perturbed in this revolution is falling back towards the parts behind and retreating from the portions in front; thus introducing a new inequality of distribution of density along the stream, superadded upon whatever inequalities of a like kind may have existed previously. Thus some parts of the stream are becoming unduly crowded with meteors. Others of the perturbations indicate that in this remarkable revolution a new sinuosity of sensible amount is being set up in the stream. These effects have been made conspicuous by the fortunate circumstance that the revolution for which the calculations have been made has happened to be one in which the perturbing forces have attained an intensity far exceeding the average.

The information supplied by this inquiry in regard to the time when the Leonid shower of next November may be expected is considerable, but far from complete. It may be stated as follows:-At the epoch 1899, November I5, the longitude of the node of the orbit for which the calculations have been made will be $53^{\circ} 4 \mathrm{I}^{\prime} 7$, a position which the earth will reach on 1899 November $15 \mathrm{~d}$. I $8 \mathrm{~h}$. It is probable, therefore, that the middle of the shower of the present year (I899) will occur nearly at this time, since the segment of the stream, for which our calcu lations have been made, is situated in the stream less than three months' journey of the meteors behind the segment which the Earth will encounter next November. This conclusion, however, rests on two assumptions : (I) That the two segments were, in 1866 , moving in orbits that did not much differ; (2) That the perturbations which these segments have since suffered have not much differed. Both assumptions are probable, but unfortunately neither is certain ; so that the prediction can only be offered with reservation. If the shower occurs at the time anticipated, it will be visible from both Europe and America.

A NEW PHOTOGRAPHIC PRINTING PAPER.

$W^{I T H I N}$ the last few months several new brands of photographic printing papers have been placed on the market, all of which are characterised by the possibility of all the manipulations involved in the exposure and development of the prints being performed in an ordinarily lighted room. The basis of most of these papers is a very slow bromide emulsion, with varying proportions of chlorides to modify its qualities for particular purposes. The paper issued under the name of "Dekko" by Messrs. Kodak, Ltd. (late the "Eastman Photo. Materials Co."), is one of this class. As stated in the circulars accom. panying the paper, its special feature is that it may be exposed, developed and fixed in an ordinary room illuminated by artificial light or weak daylight, thus doing away with the necessity of a special dark room for its treatment.

The paper may be safely handled for placing in the printing frame and developing at a distance of 8 or 10 feet from an ordinary full gas flame, or nearer if the light be turned down. With the Welsbach light or daylight it is advisable to shade the light with one thickness of orange paper.

For exposure the instructions recommend from three to five minutes at a distance of 6 or 8 inches from an ordinary gas burner for a negative of medium density. For daylight from one to two seconds at 2 feet from the shaded window will be sufficient. In this connection, however, we would urge the convenience and certainty with which these contact prints may be made by exposure to the light of burning magnesium. The light given is extremely actinic, as is at once appreciated if its spectrum be examined; it is more portable than any other illuminant, and may consequently be used where others are quite inaccessible, and as the metal in the form of ribbon is fairly pure, the light evolved from the combustion of a given length is practically constant.

The development of the paper is similar to that of ordinary bromide paper, except that the process is much quicker, full density being obtained in at most thirty seconds. The formula recommended for ordinary black tones is a mixture of hydroquinone and metol. The paper, however, lends itself readily to the production of varied tones from brown to bright red, these being obtained by variations both of exposure and developer. A special developer for warm tones is given in the printed instructions.

Fixing is carried out in the usual manner, and the prints should be washed for at least an hour, after which they are ready for mounting.

This paper will prove a useful addition to the printing papers already on the market; its simplicity of working and long range of colours obtainable recommending it for the amateur, while the professional will find it of great service for producing quantities of permanent prints of uniform appearance at any season of the year.

\section{LOCAL AUTHORITIES FOR SCIENCE AND ART INSTRUCTION.}

THE Directory issued bythe Department of Science and Art in I897, contained a section which has since become widely known, and will probably take a prominent place in educational politics for some time. The new paragraph-referred to as Clause

NO. [ 534, VOL. 59] 
vii. - reads as fullows: "In counties and county boroughs in England which possess an organisation for the promotion of secondary education, such organisation, if recognised by the Department, may notify its willingness to be responsible to the Department for the science and art instruction within its area. In such case grants will in general be made to the managers of new schools and classes, only if they are acting in unison with such organisation. The rights of the managers of existing schools and classes will not be interfered with; and Town Councils and School Boards which are managers of schools rereceiving Science and Art grants will not be debarred from estab lishing in their districts additional schools where necessary. In Wales the Intermediate Education Authority is for this purpose regarded as the authority for the promotion of secondary education." Clause vii. was repeated in the Directory for 1898 , and has, since its introduction, been the cause of considerable discussion.

The following is a complete list of those local authorities which have up to the present been accepted by the Science and Art Department as responsible for the science and art instruction within their respective areas :-

$\begin{array}{lc}\text { Cambridgeshire } & \text { CounTiEs. } \\ \text { Cumberland } & \text { Northumberland } \\ \text { Derbyshire } & \text { Nottinghamshire } \\ \text { Dorset } & \text { Oxfordshire } \\ \text { Durham } & \text { Somerset } \\ \text { Essex } & \text { Staffordshire } \\ \text { Hampshire } & \text { Suffolk (East) } \\ \text { Herefordshire } & \text { Surrey } \\ \text { Lancashire } & \text { Sussex (East) } \\ \text { Leicestershire } & \text { Sussex (West) } \\ \text { Middlesex } & \text { Westmorland } \\ \text { Norfolk } & \text { Wiltshire } \\ & \text { Yorkshire (West Riding) } \\ \text { Bath } & \text { County } \\ \text { Bolton } & \text { BorougHs. } \\ \text { Brighton } & \text { Oxford } \\ \text { Burnley } & \text { St. Helens } \\ \text { Devonport } & \text { West Bromwich } \\ \text { Torcester }\end{array}$

Just recently the application made by the London County Council to be recognised as responsible within the County of London, for the instruction in subjects sanctioned by the Department of Science and Art, has been granted.

Before referring to the opposition which has been offered by educational organisations (other than those' ultimately authorised by the Department to act under Clause vii.) to an acceptance of the claims of the public body applying for recognition, it will be advisable to call attention to certain utterances of the President and Vice-President of the Committee of Council on Education, since their remarks have served to define more clearly the scope of the new clause. His Grace the Duke of Devonshire has said "he was perfectly aware that considerable jealousy had been felt of these organisations (under Clause vii.), because it was supposed that, if largely adopted, they would probably be stereotyped hereafter by legislation as the future educational authority. He did not believe there was any ground for such jealousy or suspicion. The Government was perfectly aware that the creation of strong bodies for the control of secondary education must be the work of Parliament . . and when the time came the Government had no intention of shrinking from making their own proposals."

Such an utterance as this should go a long way towards dispelling any idea that Clause vir. is an attempt " to carry out the recommendation of the Secondary Education Committee without legislation." At a conference in June last, between the Department of Science and Art and the Organising Secretaries and other representatives of the then recognised authorities, Sir John Gorst explained that "the accepted organisations would (I) receive en b'oc the grants earned in all schools in their areas ; (2) be given power to appoint teachers in science subjects, who would not be required to possess the special qualifications laid down in the Directory; and that the work of examination and inspection would remain in the hands of the Department. It was also decided at the same conference that such local authorities should settle questions relating to the managers of different schools and their duties, and should receive examination results direct from the Department.
The opposition offered by the London School Board to the claim of the London County Council referred to above, led to an inquiry by the Department of Science and Art, and the several points raised by the School Board may be fairly taken as typical of the objections to the clause throughout the country. Amongst other matters the School Board urged that the present policy of the Department was to look upon the managers of elementary schools engaged upon higher work as intruders, and that this was inconsistent with the ideas which led to the establishment of the Department. It was argued that the granting of authority to the London County Council would be an improper prejudicing of the function of Parliament, and would be uncon stitutional ; and also that Clause vii. in operation might seriously prejudice the rights of volunteers in evening continuation science and art work, inasmuch as the County Council would under the clause have the right of vetoing what they considered to be unnecessary evening continuation work.

Such is briefly the present state of affairs. The Department of Science and Art continues to judge each application received from local educational committees, of one kind or another, upon its own particular merits, and the decision of the Department is final. The extent to which the powers of South Kensingten under Clause vii. may be modified by legislation-which appears to be imminent-remains to be seen. Time alone might perchance suffice to reconcile the objectors.

\section{A. T. Simmons.}

\section{UNIVERSITY AND EDUCATIONAL INTELLIGENCE.}

CAMBRIDGE. - The following is the speech delivered by the Public Orator, Dr. Sandys, Fellow and Tutor of St John's, in presenting for the complete degree of $\mathrm{M}$. A. honoris causa $\mathrm{Mr}$. G. Sims Woodhead, Professor of Pathology :-

"Duos deinceps pathologiae professores, fere in medio aetatis cursu morte immaturâ praereptos, non sine dolore nuper amisimus, quorum utriusque egregia in Academiam merita non est quod longius exsequar: vosmet ipsi vobiscum non sine desiderio recordamini. Hodie vero professorem talium virorum in locum nuperrime electum, morâ nullâ interpositâ salutamus, et senatus nostri in ordinem statim cooptamus. Abhinc annos viginti regiae societati medicae inter Edinenses praepositus, postea ibidem uno in quinquennio discipulorum duo milia patho. logiae praeceptis imbuisse dicitur. Idem et olim inter Berolinenses et nuper inter Londinenses maximo cum fructu his studiis operam dedisse fertur. Peritis quidem nota sunt volumina illa quae (ne alia commemorem) de pathologiae prae. sertim scientiâ conscripsit. $\mathrm{Ab}$ isdem non sine spe magnâ expectatur opus ingens, in quo de remedio novo contra diphtheriae toxicum nuper feliciter adhibito, aegrotantium numero immenso recensito, accuratissime disputat. Sunt etiam alia professoris nostri in studiis generi humano salutaria, quae memoratu sunt dignissima; sed hodie haec omnia, temporis iniquo exclusus spatio, ut Vergili verbis utar,

$$
\text { “" 'praetereo, atque aliis post me memoranda relinquo.' }
$$

"Duco ad vos Professorem Woodhead."

DR. THOMAS BARLow has been appointed to fill the vacancy in the body of the University of London Commissioners caused by the resignation of Sir William Roberts.

Science announces the following recent gifts to educational institutions in the United States :- Washington University, St. Louis, has just received generous gifts enabling it to remove to its new site facing Forest Park. This site was purchased with a fund of 200,000 dollars, contributed by seventy-five different subscribers. Funds for a library, to cost 100,000 dollars, are in the hands of the directors by the bequest of the late Stephen Ridgley. The additional buildings include an engineering building, costing 150,000 dollars, given by Mr. Samuel Cupples, and a chemistry building, costing I00,000 dollars, given by Mr. Adolphus Busch. Mr. Brookings has also offered 100,000 dollars, on condition that 500,000 dollars be subscribed at once for an endowment.-Mr. Philip D. Armour has given 750,000 dollars to the Armour Institute of Chicago, which he had previously endowed with I, 500,000 dollars. -The will of the late Alexander M. Proudfit, of New York City, gives 30,000 dollars to Columbia University for two fellowships, one in letters, and one for advanced studies in medicine.-Knox College, 